\title{
Automatic Upload of Professional Profiles Directly from Sources
}

\author{
Rui Barbosa ${ }^{1}$, Domingos Martinho ${ }^{1}$, Rui Neto ${ }^{2}$, \\ ${ }^{1}$ ISLA Santarém, Largo Cândido dos Reis, \\ 2000-241 Santarém, Portugal \\ ${ }^{2}$ Linkare TI - Tecnologias de Informação, Lda. , Avenida 5 de Outubro 77, \\ Lisboa, Portugal \\ Rui Barbosa ${ }^{1}$, rui.barbosa.portugal@ hotmail.com, \\ Domingos Martinho ${ }^{1}$, domingos.martinho@unisla.pt, \\ Rui Neto ${ }^{2}$, rneto@linkare.com\}
}

\begin{abstract}
Globalization of education and employment is a fact [1]. Also, according to one International Labor Organization report [2], 6\% of the world's work force was without job in 2012. Finally, a high development of information and communications technology (ICT) until 2020 is possible [3]. Why, then, should we go on using the conventional, complex, irksome, bureaucratic process of gathering our $\mathrm{CV}$ from often remote sources, and share it with remote Recruiters who often don't trust on it? Alternatively, it should be possible to solely supply our national identification to an Interface, and get, through national platforms, or else, our CV, expeditiously, and directly from those Sources; and to use it to apply to the Recruiting Entities, or to use them in internet platforms (LinkedIn, Times of India's, EURES, EUROPASS, Guardian's and so). We propose a methodology, and ICT system, to upgrade the CV's delivery to an expeditious and cheaper process.
\end{abstract}

Keywords: Computer Networks, Curriculum Vitae, Employment Platforms, Information and Communication Technologies, Interface, Interoperability, National platforms, Web services.

\section{Introduction}

We propose a new method of $\mathrm{CV}$ filling and transmission analogous to a money transfer in an ATM: give your identification, (in our case, the national identification) and transfer the amount of money (your CV) from your bank account (the Source Entities) to the receiver (the Recruiter Entity) (Table 1).

Table 1. Analogies between dollars and learning.

\begin{tabular}{l|l|l}
\hline Domain & Finances & Learning's \\
\hline Credits & Dollars & Learning Credits [4][5] \\
\hline Platforms & Interbank Services [6] & National Interoperability Platforms [7] \\
\hline Cards & ATM & National Identification Card \\
\hline
\end{tabular}




\begin{tabular}{l|l|l}
\hline Applications & Make Applications & Sign up for an Education or Training Action \\
\hline Actions & Pay & Apply for a Job \\
\hline
\end{tabular}

The persons, similarly to what they are already doing with payments in dollars, when wishing to pursue their studies, training or work, inside or outside their countries, should be able to get the components of their CV, automatically, just by mentioning their schools, training centres and former employers in several countries (Fig. 1).

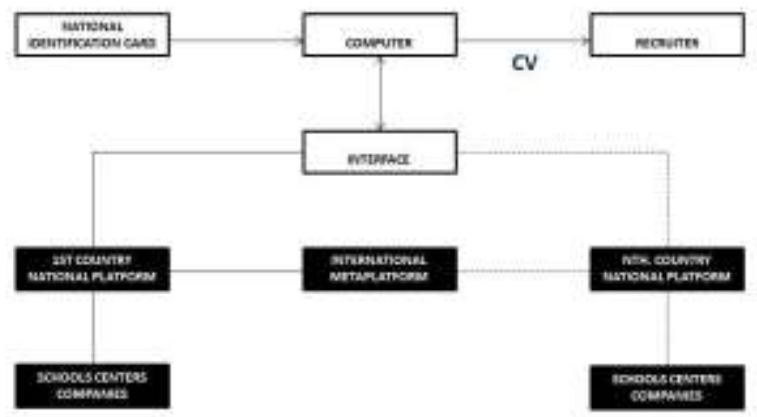

Fig. 2. Automatic upload of CV Components, from several countries

That new process should facilitate and speed-up drastically the emission of the $\mathrm{CV}$, thus making much easier the recruitment process; for instance, in Europe, where the struggle for employment was considered the first priority of the European Commission [8].

The availability and readiness of ICT has reached a state of maturity that can support the envisioned concept:

1) Secure authentication. For instance via national identity cards such as the Portuguese Citizen Card [9] [10].

2) Secure data transfer [11].

3) Reliable digital certification of information. For instance pertaining to worldwide trusted certification authorities [12] [13].

\section{Advantages of the Automatic Upload of Professional Profiles Directly from Sources}

Whereas, with the conventional methodology, the Person has to move, often physically, to the Schools, Training Centers or Companies (which are in general spread over several locations, or even countries) to get his certificates [14], to reproduce them, to upload them [15] and to deliver them to the Recruiters; with the new methodology, the User will solely indicate his National Citizen ID and the schools, training centers and former Employers, and automatically obtain his $C V$ by online connection with those entities. Therefore, the new methodology contains a 
huge potential of streamlining the applications for Education, Training, and Employment, raising them to the political frame of the Information Society [16], with the consequent speed up of the procedures, in a context of increasingly globalization of the Education and Employment.

Also, whereas, with the conventional methodology, the reliability of the certificates is often questioned, significantly delaying the whole application, with the new methodology, in which the connection is direct to the Source entities of those certificates, that reliability is reinforced.

Also, whereas, with the conventional methodology, the applications data are usually recorded manually by the Recruiters, with the new technology the data will be transferred and managed in increasingly automated ways between computers.

Further on, whereas, with the conventional methodology, the management control of the applications stream can only be done after recording by copy paste the data in the Recruiter's platform, with the new methodology, the data will become more easily available in the computers of the Recruiters, which will make that control easier, and more in time, enabling in particular to produce expeditiously statistics of all kinds, organized by different criteria. Which will simplify also, at higher hierarchical levels (city, region, nation, political block), the control, with statistics of the kind "number of applications to new scholar or training courses or employment, per candidate", "number of such applications per training area", "number of applications which were accepted", relations among Education, Training and Work, and so on.

Also, the new methodology, because it is expected to facilitate the ICT connection between the applications and the effective employment, will help solving one of the most difficult problems in Education and Training: The follow-up of the ex-students or trainees, after the end of the education or training processes.

In collaboration with the Portuguese National EUROPASS Center, the Portuguese Directorate General of the Ministry of Education for the Statistics of the Education and Science, and several other important national Portuguese entities in the fields of Education and Training, who enthusiastically welcomed our idea, we developed this new methodology, aimed at being an alternative to the conventional, complex, irksome and expensive bureaucratic process of application to Education, Training and Employment.

\section{Description}

Education and training activities that are part of a person's curriculum are usually provided by education institutions; through an online network, a User will be able to perform a request either directly or indirectly to an education institution/company, in order to receive his personal certified curriculum information, i.e., the pertaining courses or activities that he developed in that institution.

Implementation. The implementation could be done in the following way:

1) To establish a network of partner institutions:

- Educational and training institutions (such as Schools, Universities, Professional Training Centers) that can offer education certification to their former or current students. 
- Companies that can either offer certification on current or former employees' professional activities as well as take advantage of the new CV certification possibilities.

- Employment platforms that offer availability of on-line services for CV management integrated with the new automatically supplied and certified information (e.g. LinkedIn, EUROPASS on-line platform, etc...).

2) To create a technologically advanced software interface to intermediate between employment platforms and the sources of the CV (for instance using web services):

- Ensuring user identification via the national eID systems (such as the Portuguese Citizen Card) in order to guarantee secure authentication when providing information.

- Providing digital certificates along with the supplied information. These certificates will be attached to the information present on the CV guaranteeing its authenticity. They will be verified and visually shown by on-line employment platforms or other formats of digital CV's (e.g. PDF). These certificates will be managed by the correspondent supplying institutions (education, training institutions, and companies).

3) To disseminate this technological interface and network throughout other education institutions/companies/employment platforms.

Interface Over on-line Employment Platforms. This envisioned platform will present the following operational features, from the point of view of the Citizen:

1) To access the platform, on-line, and manage his CV as desired, and according to the various specific features and goals of the employment platform being used.

2) From within the employment platform, when entering information about educational/professional experience:

- To select the appropriate available options for retrieving his personal information from an institution.

- To searches and select the institution, available from the ones that are connected to the network.

- To use his national eID card, to provide secure authentication information to the institution.

- Once authenticated, the Citizen will be provided with his CV information in that institution.

- He will then be able to manage this information in a structured manner according to his $\mathrm{CV}$, and taking advantage of the fact that the information is correctly certified.

3) The Citizen will also be able to export his CV in different formats as provided by the employment platform: for instance, exporting a PDF file onto a EUROPASS format [17] or any other. This file will contain the associated digital certificate regarding the blocks of information that were supplied according to the new methodology.

4) The information architecture to be implemented in the platform will be object of a profound analysis during a state-of-the-art work package.

5) The Citizen will then be able to share his information publicly or more or less restrictedly within the employment platform used. Sharing it with possible employers or using it directly to submit on-line employment applications. 
Automatic, Accurate and Standard Presentation of Information. This new methodology will allow for automatic, accurate and standard presentation of information on the Citizen's CV, Either within a given employment platform as well as in generated documents.

The Digital certificate can be validated and shown as valid or invalid within an employment platform or when opening a digital CV.

For secure authentication, aiming at the simplification and standardization of the new methodology, the implementation is thought to be performed via the national provider for citizen authentication in each Project's Partner Countries.

In Portugal, for instance, the national Agency for the Modernization of the Administration - AMA - provides an interoperability platform for authentication with the Portuguese Citizen Card [18] [19] [20]. It is possible to use AMA's interoperability platform to perform authentication with any institution. This will allow all the institutions to supply information through a national and trusted public service (Fig. 1).

Similar national authentication services exist, for instance, in Belgium - provided by BE FEDICT, as well as in Spain - provided by MPT. These national agencies provide such authentication services in the scope of the meta-platform STORK [21] and are able to interact between themselves across borders. To provide a CV platform via these STORK national agencies will allow automatic interoperability of the platforms between the different countries in the project, independently of the authentication eID system used in each one of them.

Manual and Toolbox. A Manual and Toolbox should be created containing documentation and the specifications necessary for institutions to connect and integrate their on-line services to this Interface. Those two items should contain all necessary information and requirements to implement this communication interface with an institution's services.

\section{Future projects: "Googling" the CV components from their Sources}

Alternatively, the implementation could, theoretically, be done in a more structured way. Within each country, connection of the Schools, Training Centers, Companies to the National Education, Training and Work platforms, and of these to the National Interoperability Platforms. The production of the $\mathrm{CV}$ could be more automatic: the User should have to identify himself, and, solely, ask for his CV, which could be composed automatically using a google-type search for the CV components in the different national platforms concerned (Fig. 2).

The economical blocks, similarly to what happens in Europe, should have the preoccupation of clarifying and harmonizing the diverse Education, Training and Employment systems, in order to facilitate the mobility of citizens, thus lubricating the work market. For the emission of the $\mathrm{CV}$, we don't see, nowadays, a better ICT methodology to be used than this that we just presented. 


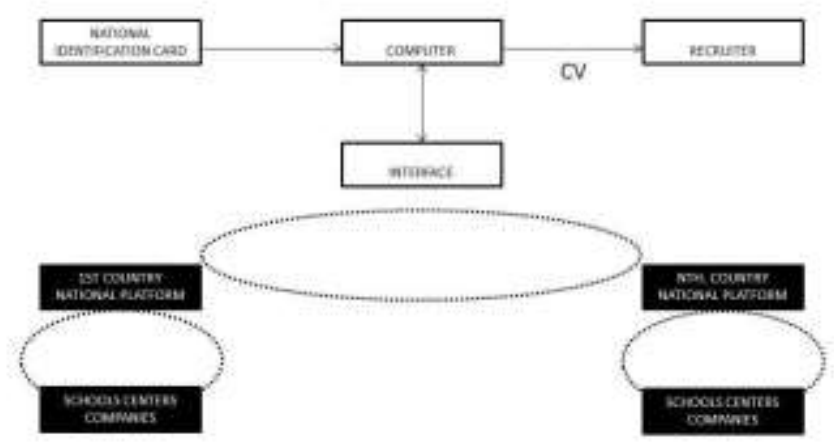

Fig. 2. Automatic upload of CV components from several countries.

Example taken from European EURES system "The pan-European job search network EURES would be strengthened to provide more job offers, increase the likelihood of job matches and help employers, notably small and medium businesses, to fill job vacancies faster and better" [22], under a proposal presented by the European Commission.

Once adopted by the EU's Council of Ministers and the European Parliament, the proposal would help citizens to make the most informed choice possible when it comes to moving abroad for work.

The proposed new rules would make EURES more efficient, recruitments more transparent and cooperation among Member States stronger, notably by allowing EURES to (...) carry out automatic matching through job vacancies and CVs" [22].

The "automatic matching" could very probably be implemented through Artificial Intelligence computer applications. How? With an intelligent computer application, while a Human Resources Specialist could "teach", i.e. program the system to verify that the Candidate's Profile fits, or not, to the Application requirements, the Human Resources Technicians could solely "ask" the computer to verify it automatically (although under their supervision); the answer being either a straight acceptance, or the listing of the credits missing for that acceptance.

\section{Conclusions}

We just described a new concept for people to get their $\mathrm{CV}$ in a much more expeditious and simple manner, and what should be the most effective implementation of that concept taking into account the present state of the technologies. It would certainly change the present framework, leading it to the Society of Information framework [16].

This new methodology would benefit drastically all those, searching a new education or training, or employment [23], which is in their majority young and becoming increasingly familiar with computers, to get out much more easily of their 
often dramatic situation. The ICT solution we propose is in line with the technological evolution (hyper-connected human framework) [24], and its spreading to new communities and to new devices, with the predicted decrease of its cost.

Acknowledgements. The Authors thank the Portuguese EUROPASS Centre, for many contributions and corrections, the Portuguese Interbank Services Society, for the information given, Prof. José Tribolet, Department of Computer Science Engineering, Higher Technical Institute, U. Lisbon, Portugal, and Mrs. Ana Duarte Monteiro, Editorial Coordinator, HR Publisher, Portugal.

\section{References}

1. International HRM, Contemporary Issues in Europe; Ed. C. Brewster and H. Harris; First published 1999 by Routledge; ISBN 0-415-19489-X (hbk); ISBN 0-415-19490-3 (pbk).

2. Wikipedia, Unemployment; http://en.wikipedia.org/wiki/Unemployment.

3. Kaku, Michio; "Visions - How Science Will Revolutionize XXI Century"; www.amazon.com

4. E. Kula, M. Penkowska; Validation of Informal and Non-Formal Education Results and Lifelong Education; in Lifelong Learning, Continuous Education for Sustainable Development, Proceedings of 11th International Cooperation Volume 11- Part I, Editors N.A. Lobanov, V.N. Skvortsov (2013)

5. Lifelong Learning Policy; http://ec.europa.eu/education/lifelong-learning-policy/ framework_en.htm

6. SIBS; Superbrand 2014; @ C SUPERBRANDS (UK), SIBS FPS; www.sibs.pt/.

7. Interoperability Solutions for the European Public Administrations; http://ec.europa.eu/isa/.

8. European Commission; "The Commission and its Priorities"; http://ec.europa.eu/priorities /jobs-growth-investment/index_en.htm (2012)

9. The key to public and private sector convergence, Jonas Andersson (2009)

10. Digital Signature Pilot Test for Academic Records, Martinez-Vara de Rey, J.F. ; Serra Cifre, B.J., Latin America Transactions, n², Vol:3, Issue: 2, p. 205 - 219 (2005)

11. Web Services Security, Mark O'Neill, McGraw-Hill Osborne Media (2003)

12. Electronic Signature and Infrastructures (ESI), Technical Specification, ETSI - European Telecommunications Standards Institute (2007)

13. Beattie, D., Bailey, C.T.M., Creighton, N.L. Remy, D.L., Hamandi, H.; Methods and systems for automated authentication, processing and issuance of digital certificates; http://www.google.com/patents/CA2463504A1?cl=en (2003)

14. CV-DNA, "We certify your professional DNA"; http://www.cvdna.com/pt.

15. Software to Write your Curriculum Vitae; http://articles.informer.com/software-to-writeyour-curriculum-vitae.html.

16. Digital Agenda For Europe; http://ec.europa.eu/digital-agenda/en.

17. EUROPASS; http://europass.cedefop.europa.eu/.

18. Portuguese Citizen Card; www.cartaodecidadao.pt/

19. Agência para a Modernização Administrativa; www.ama.pt

20. Interoperabilidade na Administração Pública; www.iap.gov.pt

21. European Stork - Pilot 3 Student Mobility - To help people who want to study in different Member States; https://www.eid-stork.eu/pilots/pilot3.htm

22. EURES - European Commission; ec.europa.eu/eures/page/homepage

23. Higher Institute of Languages and Administration ISLA, Santarem, Portugal, Center for New Opportunities; Final Report (2012)

24. Futurium - European Commission; ec.europa.eu/digital-agenda/futurium/ 